\title{
Motyw szycia i haftu w najnowszej polskiej literaturze dla dzieci dotyczącej Zagłady
}

\author{
The theme of sewing and embroidery in the latest \\ Polish children's literature about the Holocaust
}

\author{
|Agnieszka Kwiatkowska \\ Uniwersytet im. Adama Mickiewicza w Poznaniu \\ IORCID: 0000-0002-5178-631X
}

\begin{abstract}
The motif of thread and the related activities of weaving, spinning, sewing are of great importance in the Jewish culture It also plays an important role in the recent Polish children's literature devoted to the subject of the Holocaust. Knitting Jewish women are reminiscent of ancient Parkas, the thread is often the symbol of the bond that ties the protagonists; it shows the way of escape and constitutes the matter which can be changed, repeating the creative gesture of God. Above all, it is the metaphor of memory - a story of the past which introduces its plot into the collective consciousness.

Key words: thread, yarn, weaver, sewing, embroidery, Holocaust, children's literature

Streszczenie: Motyw nici i powiązanych z nimi czynności tkania, przędzenia, szycia jest niezwykle istotny w kulturze żydowskiej. Odgrywa też ważną rolę w najnowszej polskiej literaturze dla dzieci poświęconej tematowi Zagłady. Żydówki dziergające na drutach przypominają antyczne Parki, nić często jest symbolem więzi łączącej bohaterów, wskazuje drogę ucieczki i stanowi materię, którą można przemieniać, powtarzając stwórczy gest Boga. Przede wszystkim jest metaforą pamięci - opowieścią o przeszłości, która wprowadza swój wątek do zbiorowej świadomości.
\end{abstract}

Słowa kluczowe: nić, przędza, tkacz, szycie, haft, Zagłada, literatura dla dzieci

Pan tak przemówił do Mojżesza: (...) Uczynisz przybytek z dziesięciu tkanin uczynisz go z kręconego bisioru, z fioletowej i czerwonej purpury, z karmazynu - z cherubami wykonanymi przez biegłego tkacza. Długość poszczególnej tkaniny winna wynosić dwadzieścia osiem łokci, a szerokość poszczególnej tkaniny cztery łokcie; wszystkie zaś tkaniny winny mieć jednakowe wymiary. Pięć tkanin będzie powiązanych ze sobą - jedna z drugą, podobnie drugie pięć tkanin będzie powiązanych ze sobą jedna z drugą. I przyszyjesz wstążki z fioletowej purpury na brzegach jednej tkaniny, gdzie winna być spięta, i tak też uczynisz na brzegach ostatniej tkaniny, gdzie winna być spięta. Pięćdziesiąt zaś wstążek przyszyjesz do jednej tkaniny i pięćdziesiąt wstążek przyszyjesz do drugiej tkaniny w miejscu, w którym mają być spięte, tak żeby wstążki były przyszyte naprzeciw siebie. Ponadto przyszyjesz pięćdziesiąt złotych kółek i zwiążesz tkaniny przy pomocy tych kółek, i przybytek będzie stanowił jedną całość (Wj 25,1; 26, 1-6). 
W taki sposób patriarcha Izraela przygotować miał Namiot Spotkania - święty przybytek, w którym przechowywana będzie Arka Przymierza. Tkanie, szycie, haftowanie stały się więc potwierdzeniem i podtrzymaniem Przymierza, jakie Jahwe zawarł z Mojżeszem na górze Horeb. Czynności te nie tylko powtarzają akt kreacji, ale przynoszą potwierdzenie boskiej obecności i pozwalają odszukać poczucie łączności ze Stwórcą. Żydowskie baśnie i podania, historie zaczerpnięte $\mathrm{z}$ midraszy pełne są postaci krawców, tkaczy - zwykle mądrych i roztropnych, wykazujących się życiowym sprytem, w swej pracy naśladujących dzieło stworzenia.

We współczesnej literaturze dla dzieci dotykającej tematu Zagłady motywy te pojawiają się bardzo często, budują metaforyczną warstwę znaczeń, naprowadzają odbiorcę na odpowiedni trop interpretacyjny i każą szukać historycznej prawdy, tak okrutnej, że niemożliwej do ubrania w słowa. To, czego nie da się zwerbalizować, zostaje więc w pewnym sensie wyhaftowane czy uszyte, a nić opowieści snuje się zarówno w dosłownym, jak i w metaforycznym sensie. Książki adresowane do najmłodszych czytelników unikają epatowania okrucieństwem, uciekają się do baśniowej transformacji estetycznej (Wójcik-Dudek 2016, 158) i najstraszliwsze historyczne fakty pozostawiają w sferze sugestii, odwołując się do wiedzy czytelnika, pochodzącej z innych źródeł lub do potencjalnych komentarzy dorosłych wygłaszanych podczas wspólnej lektury. Nić jest przewodniczką w poszukiwaniu prawdy i tworzywem, z którego powstaje gobelin ostatecznej opowieści. Motyw nici i powiązanych z nią czynności odgrywa szczególnie istotną rolę w książkach: Pamiętnik Blumki Iwony Chmielewskiej, Ostatnie przedstawienie panny Esterki Adama Jaromira i Gabrieli Cichowskiej, Mama zawsze wraca Agaty Tuszyńskiej i Iwony Chmielewskiej, Bezsenności Jutki Doroty Combrzyńskiej-Nogali i Wysiedlonych tej samej autorki.

\section{Żydowskie Parki}

Nić jest przędzą ludzkiego losu w rękach żydowskiej Parki, znakiem międzyludzkich więzi, układa się w wydziergany na drutach obraz świata, pomaga wyznaczyć drogę i stanowi tworzywo, które może posłużyć do korekty otaczającej rzeczywistości. W kulturze ludowej tkaniu, przędzeniu i szyciu przypisano bogactwo znaczeń. Większość takich zajęć uchodzi za typowo kobiece, a towarzyszący im ruch wahadłowy czy obrotowy staje się wizualizacją kategorii temporalnych, podczas gdy nić stanowi symboliczny ekwiwalent człowieczego losu (Gołębiewska-Sucholeska 2018). Na obrazach Aleksandra Gierymskiego Żydówki handlujące owocami, w oczekiwaniu na zainteresowanie kupujących, dziergają na drutach kolejne chusty czy pończochy. Zamyślone spoglądają w dal i gdy tak sprawnie przesuwają w palcach nić, przypominają mityczne Prządki - strażniczki ludzkiego losu. W taki sposób zapamiętała swoją żydowską sąsiadkę mała Kazia Łobodziec, bohaterka książki Doroty Combrzyńskiej-Nogali Wysiedleni, mieszkanka 
Gródka Jagiellońskiego położonego nieopodal Lwowa, bystra obserwatorka przedwojennej rzeczywistości. Dziewczynka (z jej perspektywy bowiem prowadzona jest narracja) opowiada o wielokulturowym sąsiedztwie, o przeplatających się i nakładających na siebie świętach katolickich obchodzonych przez Polaków, prawosławnych - ważnych dla Ukraińców i żydowskich, które polskiemu dziecku kojarzyły się przede wszystkim ze smacznym poczęstunkiem. Kazia, wielbicielka cymesu i purymowego przysmaku - słodkich uszu Hamana, zafascynowana była robotami dziewiarskimi i często przyglądała się, jak spod zręcznych palców żydowskich sąsiadek wychodziły kolorowe dzianiny.

Żydówki świetnie robią na drutach. Zawsze podziwiam migotanie cienkich, metalowych drutów i magicznie powstające swetry, szaliki, skarpety. (...) Zanim Żydzi zniknęli, kobiety żydowskie przekazały mi umiejętność robienia swetrów i szalików na drutach, żeby przetrwać zimę. Pewnego dnia przyszłam po zakupy. Zmartwiona Peśka siedziała przed sklepem, a z kolan spływała jej czerwona chusta. Zafascynowana przyglądałam się tworzonej z wełny dzianinie (Combrzyńska-Nogala 2018, 15, 21).

Sklepikarka, dziergająca czerwoną chustę, przypomina antyczne Parki czy tkającą gobelin Arachne. Na ilustracji Magdaleny Koziełł-Nowak (Combrzyńska-Nogala 2018, 23) tkanina spływa z kolan Peśki i Kazi, wypełnia płaszczyznę kartki intensywną, falującą czerwienią, przywodząc na myśl biblijną przeszłość żydowskiego narodu i cudowne przejście przez Morze Czerwone, ale zwiastując też morze krwi, którą wkrótce przeleją Żydzi z Gródka, Lwowa, z setek innych miejscowości ówczesnej Polski. Czerwona chusta sama w sobie staje się opowieścią i zwiastunem nadchodzącej przyszłości. Przedstawiona na ilustracji Peśka, która towarzyszy małej Kazi w pierwszych próbach dziewiarskich, trzyma w rękach kłębek wełny, jak gdyby czuwała nad prawidłowym rozwijaniem się nici - nad tym, jak płynie ludzkie życie i jak snuje się opowieść.

\section{Powiązani}

Czerwona włóczka w tajemniczy sposób łączy obie kobiety - małą Polkę i starzejącą się Żydówkę - które zapobiegliwym dzierganiem zapewniają bliskim ciepłą odzież, tym samym wpisując się w metafizykę krzątactwa (Brach-Czaina 1999, 23), przystępując do wspólnoty strażniczek ludzkiego istnienia. Kazia nigdy nie zapomni starej Peśki, a dzierganie na drutach będzie dla niej nie tylko pożytecznym zajęciem, ale również formą pamięci o sąsiadce i innych Żydach, którzy zniknęli z Gródka Jagiellońskiego. Nawet kilkuletnie dzieci, takie jak Kazia i jej koleżanki, wiedzą, że zostali oni przetransportowani do obozu w Bełżcu lub „rozstrzelani w lesie nad wielkim wykopanym rowem, kiedy Niemcy likwidowali getto" (Combrzyńska-Nogala 2018, 21).

Czerwona nić jako znak więzi, w tym przypadku łączącej matkę i córkę, pojawia się także w ilustracjach tomu Mama zawsze wraca Agaty Tuszyńskiej i Iwony Chmielewskiej. Stanowi gwarancję, że „mama nie może swojej 
córeczki zostawić" (Tuszyńska, Chmielewska 2020), a jej kolor odwołuje się do niezbywalnych więzów krwi i przywodzi na myśl emocjonalną pępowinę - widoczny znak relacji, wzajemnych zależności, drogę którą przekazywane są życiodajne substancje. Matka, ucząc maleńką Zosię haftowania, buduje $\mathrm{w}$ niej wolę życia, wiarę w piękno tworzenia i pokazuje, że praca z materią nieożywioną jest wyrazem troski o drugiego człowieka i próbą ulepszenia otaczającej rzeczywistości. Szacunek dla rzeczy, z których można coś wytworzyć, i poczucie matczynej miłości splatają się ze sobą, znajdując wyraz w pierwszych wyplatankach dziewczynki.

W powieści Bezsenność Jutki Doroty Combrzyńskiej-Nogali na drutach dzierga dziadek głównej bohaterki, który sprzedając czapki, swetry, szaliki, zarabia na utrzymanie rodziny zamkniętej w łódzkim getcie. Ofiarował wnuczce ciepłe rękawiczki, które dziewczynka gotowa jest dzielić z kolegą z podwórka podczas wspólnej zabawy na śniegu. Jutka doskonale wie, jak cenna jest wełna i ile pracy dziadek włożył w przygotowanie takiego prezentu, ale ma w sobie wiele empatii i wysoko ceni międzyludzką solidarność. Takiej postawy nauczyła się właśnie od dziadka, który z włóczkową robótką przysiada wieczorami na krawędzi jej łóżka i snuje pouczające opowieści, kształtujące charakter dziewczynki.

\section{Niciane światy}

W świadomości ludowej - potwierdzają to baśnie - motywy tkania, szycia, przędzenia były nierozerwalnie związane z aktem tworzenia i stanowiły symboliczne przejście $\mathrm{z}$ chaosu do ładu, przemieniając bezkształtne tworzywo w gotową i znaczącą formę (Gołębiewska-Suchorska 2018). W sytuacjach kryzysowych czynnościom tym baśnie nadają wymiar sakralny i funkcję przywracania pierwotnego ładu stworzenia (Gołębiewska-Suchorska 2018). Dziadek Jutki dziergający na drutach, Aron szyjący koszulki dla dzieci w Korczakowskim sierocińcu czy Zosia, która haftuje wzorki na dziurkowanej tekturce - wszyscy oni mniej lub bardziej (nie)świadomie próbują odtworzyć prymarny porządek i odbudować poczucie harmonii, choć ich próby zwykle spełzają na niczym lub przynoszą tylko krótkotrwałą pociechę.

Nici są materią, która służy do przemieniania świata, pozwala tworzyć światy alternatywne, choć na chwilę pomaga w ucieczce od okrutnej rzeczywistości. Mała Zosia, która w czasie okupacji godzinami siedzi samotnie, schowana w komórce na węgiel, oczekując powrotu mamy, wypełnia swój czas dziecięcym haftowaniem. Mama dziewczynki podziurawiła kawałek tektury i nauczyła córeczkę, jak przewlekać sznurek przez dziurki, aby na powierzchni kartonu powstawały różne wzory. Po latach dorosła Zofia tak opowiada:

Pokazała mi, jak ten sznurek wkłada się do jednej i do drugiej dziurki. Miałam trzy lata, siedziałam w tej komórce i wiązałam, przekładałam. Starałam się, a ona miała łzy w oczach ze wzruszenia. Czułam, że cokolwiek robię, to jest coś niesamowitego. 
(...) Opowiedziała mi, że znalazła na ulicy stary sweter, spruła go i zrobiła takie kuleczki, trochę brudne, trochę podarte. Ale powiedziała, że to skarb i dla mnie to był skarb. I o tym chciałam opowiedzieć. Jak mama nauczyła mnie haftować. Właściwie nie nauczyła, ale dała mi taką miłość, taki... jak to się mówi po polsku... honor, respekt, szacunek - do nici, do wełny, do rzeczy, z których można coś zrobić (Tuszyńska, Chmielewska 2020).

Mama w getcie nie haftuje ozdobnymi nićmi, walczy o przetrwanie, wychodzi z piwnicy, aby zdobyć coś do jedzenia. Jej obecność naznacza jednak świat wokół Zosi, jak gdyby przemieniał się on w cudowną, pokrytą haftami tkaninę i z miejsca przeklętego stawał się świętym przybytkiem. Na jednej z ilustracji matka mimochodem dokonuje transformacji złowrogiego pejzażu - dźwigając worek ziemniaków, zbliża się do czarnej, obrośniętej jemiołą topoli. Gdy minie drzewo, jego gałęzie pokryją się haftowanymi różami, a niebo zajaśnieje błękitem, przypominając wzorki na sukience Zosi i jej lalki. Powracająca mama „zwykle była uśmiechnięta i przynosiła różne rzeczy" (Tuszyńska, Chmielewska 2020), z kieszeni płaszcza wyjmowała jabłka, marchewkę. Sprawiała, że w ciasnej komórce na węgiel żyło się „zupełnie jak w Zakopanem” (Tuszyńska, Chmielewska 2020), a urządzając skrytkę dla Zosi, żartowała: „będziesz tu mieszkała jak krasnoludek" (Tuszyńska, Chmielewska 2020). Była hafciarką wyobraźni, kreatorką światów, do których można było uciec przed napierającą zewsząd rzeczywistością. Dorosła Zofia prowadziła studio haftu w Jerozolimie, ale kiedy zaproszono ją do Muzeum Izraela, aby opowiedziała o swojej pracy, nie chciała mówić o kulturze żydowskiej i o sakralnych haftach na szabasowych obrusach. Postanowiła mówić o dziecięcym hafcie, którego nauczyła ją mama, dzieląc się cudowną mocą przemieniania rzeczywistości.

Aron, bohater Pamiętnika Blumki, miał mniej szczęścia - nie został wielkim krawcem, jak dziadek, choć wykazywał wielkie zdolności w tym kierunku. Ilustracja na wewnętrznej stronie okładki przedstawia suszące się śnieżnobiałe koszulki przypięte klamerkami nie do sznura lecz do paska papieru, do interlinii zeszytu, w którym Blumka notowała swoje obserwacje. Tak przedstawiła małego krawca:

To jest Aron, który często płacze w nocy, ale w dzień już niczego nie pamięta. Aron słynie z tego, że najlepiej z nas szyje, lepiej niż dziewczynki. Równiutko zszywa dziury w pościeli, przyszywa łaty na ubraniach dzieci i oberwane guziki. Może w przyszłości zostanie wielkim krawcem, jak kiedyś dziadek? (Chmielewska 2011).

Na ilustracji, która towarzyszy prezentacji chłopca, widać wykrój kamizelki i powłoczkę na poduszkę uszyte z tkaniny przypominającej papier z pamiętnika Blumki. Z powłoczki kapie woda, jakby zaprojektowana przez Arona pościel opłakiwała jego rychłą śmierć i Zagładę całego narodu (Sikorska, Smyczyńska 2014). Z kałuży pije wodę haftowany ptaszek, który mógłby symbolizować odradzające się życie, lecz nić, którą go wyszyto, została zerwana. Daremnie Aron próbuje ponownie nawlec igłę, kontynuować pracę, podtrzymać linię życia. Koszulki przezeń uszyte już wkrótce 
nie przydadzą się nikomu, a on sam spotka się z dziadkiem - wybitnym krawcem przyglądającym się wnukowi z zaświatów.

Szycie Arona nie zmieni świata, nie wykreuje bezpiecznej rzeczywistości, w której mogłyby się schronić dzieci z sierocińca. Opowieść Blumki jest formą lamentacji, w której linie zeszytu i szwy dziecięcych koszulek to znak pamięci o tych, którzy odeszli na zawsze. Aron nie przypomina w niej wszechmocnego Stwórcy-Tkacza, jest raczej podobny do Leśmianowskiego szewczyka, który codziennie na nowo podejmuje trud szycia/życia, utożsamiając ze sobą te dwa zadania (Grądziel-Wójcik 2017, 8), z każdym ściegiem zbliżając się do nieuchronnego kresu. W jednym z baśniowych podań, zapisanych przez Oskara Kolberga, przetwarzającym biblijny motyw wieży Babel, demoniczne Sybille szyją koszule, napędzając upływ czasu i przybliżając tą czynnością nieuchronny koniec świata - „jak uszyją: to świat się skończy (...), co raz dźgną igłą, to rok minie" (Gołębiewska-Sucholeska 2018). Utrzymane $\mathrm{w}$ wahadłowym porządku czynności tkania, szycia czy przesuwania kolejnych rzędów dziewiarskiej roboty przywodzą na myśl rytm żydowskich modlitw, jakby były szczególnym kadiszem, który bohaterowie odmawiają za siebie i za swoich bliskich. Jeśli zabraknie dziesięciu dorosłych Żydów, którzy mogliby odmówić modlitwę w intencji zmarłych, nici wplecione w zbiorową świadomość dadzą świadectwo pamięci.

\section{Metafizyczna podszewka}

W picture booku Adama Jaromira i Gabrieli Cichowskiej Ostatnie przedstawienie panny Esterki tytułowa bohaterka, pracująca jako opiekunka w warszawskim sierocińcu, postanawia zabsorbować dzieci przygotowaniami do spektaklu teatralnego. Egzotyczna, przeniknięta atmosferą hinduskich baśni sztuka Rabindranatha Tagore Poczta skutecznie pochłania uwagę wychowanków, przejętych historią nieuleczalnie chorego Amala, więzionego w domu wujostwa. Panna Esterka włożyła dużo wysiłku w to, aby zorganizować kostiumy dla małych aktorów, poświęciła nawet swoją najładniejszą sukienkę. Jednak z mieszkanek sierocińca, odtwórczyni hinduskiej tancerki tak to komentuje:

Mam grać Sudhę, dziewczynkę z kwiatami. To mała rola, ale panna Esterka powiedziała, że Sudha nie na darmo nosi dzwonceczki u stóp. Obiecała nauczyć mnie tańca (...). Pani Blimka obiecała uszyć mi sukienkę. Materiał na nią dała jej panna Esterka. Spruła po prostu letnią sukienkę. Swoją najładniejszą. Tę, którą chciała włożyć w dniu, w którym skończy się wojna (Jaromir, Cichowska 2014).

Panna Esterka, prując suknię, rezygnuje ze swoich marzeń, aby podopiecznym zapewnić możliwość ucieczki w krainę wyobraźni podsycanej sztuką. W zderzeniu z okrutną rzeczywistością mityczna szwaczka pozostaje bezradna - nawet najzręczniejsze ręce nie zaczarują świata, nie zatrzymają tego, co nieuchronnie się zbliża. Gest oddania sukni ze strony panny Esterki to pożegnanie z realnie pojmowanym życiem, w którym najwyższą wartością 
jest przetrwanie. Przeróbka odświętnej sukni na teatralny kostium każe skierować uwagę ku sprawom wyższym, szukać ocalenia lub choćby tylko chwilowego zapomnienia w sztuce, która jest wyrazem tęsknoty za nieskrępowaną wolnością. Trzy tygodnie po wystawieniu Poczty dzieci z sierocińca, wraz ze Starym Doktorem, powędrowały na Umschlagplatz. Pannę Esterkę aresztowano kilka dni wcześniej podczas łapanki.

W baśniach „wymagający czasu proces szycia symbolizuje powolną przemianę, niejako narodzenie od nowa" (Gołębiewska-Sucholeska 2018). Zarówno Aron, jak i panna Esterka uczestniczą w procesie przemiany, stając się przewodnikami rytualnego przejścia. Uszyte przez Aronka śnieżnobiałe koszulki, jak gdyby opuszczone, pozostawione przez właścicieli odsyłają do świata pozazmysłowego podobnie jak biel lilii niesionej przez Esterkę czy światło spływające na postać Doktora. Teatralny kostium przygotowany z sukienki panny Esterki pozwala małej dziewczynce na chwilę stać się hinduską tancerką i schronić się przed wojną w alternatywnej rzeczywistości. Okazuje się jednak, że problemy samotności, opuszczenia, ograniczenia wolności, poruszane w sztuce Rabindranatha Tagore, nie straciły swej aktualności i przystają do straszliwych czasów, a przedstawienie staje się formą pożegnania z wychowawczynią i ostatecznie z samym życiem. Przerwanie nici, którą Aronek wyhaftował ptaszka, czy zniszczenie sukni i sprucie ściegów wskazuje na koniec życia lub jednej z jego faz (jak ukłucie się wrzecionem w baśni o Śpiącej Królewnie). Panna Esterka rozstaje się z marzeniami o zakończeniu wojny, a mały chłopiec odważnie wędruje tam, gdzie czeka już na niego dziadek.

Metafora sukni - rozumianej jako drugie „ja” - rozpruwanej, przerabianej, szytej - determinuje rozważenie wątków tożsamościowych, łączących problematykę cielesną i metafizyczną, ujawniających równoczesne zaangażowanie w doczesność i wieczność (Grądziel-Wójcik 2017, 9). Rzeczywistość jest nie do zniesienia, nadzieja na zakończenie wojny staje się coraz bledsza, więc gest poprucia sukienki stanowi nie tylko znak ofiary, ale i rezygnacji. Panna Esterka odcina się od codzienności i doczesności, wie już, że „tutaj” nie czeka jej żadna przyszłość, spogląda na "tamtą" stronę. Kostium na przedstawienie, który kazała uszyć ze swej sukienki, to szata umożliwiająca rytualne przejście do świata duchowego. Teatr w Ostatnim przedstawieniu panny Esterki ma bowiem wymiar sacrum i uruchamia metafizyczny aspekt rzeczywistości. Jak skrzydła Dedala czy nić Ariadny w Bezsenności Jutki, sztuka Rabindranatha Tagore daje nadzieję, że można wydostać się $\mathrm{z}$ więzienia.

W magicznych baśniach ludowych kłębki nici, narzędzia przędzalnicze czy tkackie, pozyskane od pozytywnie usposobionych darczyńców, pomagają bohaterom pokonać przeszkody, ominąć niebezpieczeństwa bądź poruszać się w zaświatach (Gołębiewska-Sucholeska 2018). W pewnym sensie taką właśnie rolę pełnią kłębki podartej wełny, które mama ofiarowała małej Zosi. Dziewczynka zajmuje się dziecięcymi wyplatankami i dzięki temu 
znosi jakoś samotność, strach i oczekiwanie na powrót mamy. Baśniowa nić często wyznacza szlak w przestrzeniach niebezpiecznych i pozwala odnaleźć właściwą drogę. Jutka (z Bezsenności Jutki) ma poczucie, że ugrzęzła w labiryncie, ale znajduje pociechę w mitologicznych opowieściach, jakie dziadek snuje w bezsenne noce. Dziewczynka marzy o tym, aby wzlecieć ponad mury getta i uciec ze znienawidzonego miejsca, wzorem Dedala i Ikara, lub wymknąć się z potrzasku jak Tezeusz, krocząc śladem nici darowanej z miłością. Na jednej z ilustracji dziadek przysiadł na krawędzi łóżka, w którym zasypia dziewczynka, a wełna z jego robótki tworzy na podłodze wzór przypominający labirynt. Na innym rysunku Jutka siedzi u podnóża schodów, trzymając w rękach kłębek wełny, i tęsknie zerka w górę, ku światłu, w kierunku, który wskazuje nić. Opowieści dziadka pozwoliły Jutce przetrwać w getcie, a jego starania ostatecznie umożliwiły dziewczynce ucieczkę. Mityczna nić Ariadny prowadzi do zabicia niewinnego - Minotaura uwięzionego $\mathrm{w}$ labiryncie ${ }^{1}$, ale pozwala również wydostać się z więzienia, prowadząc ku wyjściu z mroku, w stronę wyzwolenia i wolności.

\section{Nić pamięci}

Nić jest też znakiem snucia opowieści - prawdy o minionych wydarzeniach, świadectwem tożsamości i świadomości, znakiem pamięci. Nie przypadkiem na jednej z ilustracji w książce Mama zawsze wraca oplata ona nieistniejące fotografie, tworząc ramki między celuloidowymi narożnikami albumu. Główna bohaterka opowieści ma tylko jedno zdjęcie mamy, które zrobiono 20 sierpnia 1942 roku, pięć dni po ucieczce z getta. Dzieci ocalone z Zagłady rzadko kiedy zdołały ocalić zdjęcia i rodowe pamiątki, które - jak pisze Susan Sontag - mogłyby stać się mostem między pamięcią a postpamięcią (Sontag 1986, 34). Ukrywane po aryjskiej stronie, obdarzone nową tożsamością często musiały zapomnieć o swojej pierwszej rodzinie, bo dziecięca psychika nie była w stanie udźwignąć przekonującego odgrywania roli i ciężaru podwójnego istnienia. Fotografie i inne pamiątki łatwo mogłyby stać się przyczyną dekonspiracji, stanowiłyby więc ogromne zagrożenie. Możliwość odtworzenia pamięci daje więc opowieść - przekazywana młodszym przez starszych, odtwarzana samemu sobie czy wreszcie spisywana dla przyszłych pokoleń. Ramki zakreślone czerwoną nitką wyznaczają przestrzeń pamięci, swoiste lieux de mémoire (Nora 1974, 401; Szpociński 2008, 12), bowiem opowieść oddaje świadomości zbiorowej to, co od zawsze powinno do niej należeć.

Mirabelka, rosnąca na podwórku warszawskiej kamienicy w powieści Cezarego Harasimowicza, towarzyszy mieszkańcom Nalewek w ich codziennym życiu, między innymi obserwuje rozwój fabryczki braci Alfusów, produkujących stroje karnawałowe, zdobione koralikami i cekinami. Właściciele intratnego biznesu są mocno wpisani w lokalną społeczność - obdarowują

\footnotetext{
${ }^{1} \mathrm{~W}$ ten sposób reinterpretują mit m. in. Jorge Luis Borges (Dom Asteriona, 1949) i Zbigniew Herbert (Historia Minotaura, 1974).
} 
błyskotkami dzieci sąsiadów, oferują pracę i uczestniczą w rodzinnych uroczystościach. Garść koralików dostała od nich mała Dorka, która nawlekła je na nitkę i założyła w święto Pesach. Niesforne koraliki ciągle wysmykują się spod kołnierza płaszczyka dziewczynki, stanowiąc barwny akcent w świecie zbliżającej się apokalipsy. Mieszkanka kamienicy na Nalewkach jest bowiem pierwszą z szeregu dziewczynek w czerwonych płaszczykach, które pojawią się na kartach Mirabelki, kolejno - jak bohaterka powieści Romy Ligockiej² - stając się ofiarami historii. Koraliki braci Alfusów na zawsze wpiszą się w przestrzeń Nalewek. Rozsypane podczas ślubu Dorki z Chaimem zmieszają się z podwórkową ziemią, z której czerpie życiodajne soki mała mirabelka. Kolejne pokolenia mieszkańców tej dzielnicy będą je tu znajdować i cieszyć się ich barwami - młody warszawski budowniczy zrobi z nich naszyjnik dla swojej dziewczyny, mała Dorotka podobną ozdobę ofiaruje w prezencie swojej mamie. Koraliki nawlekane na nitkę są jak okruchy ludzkich losów i jak ludzkie biografie, które składają się na historię Nalewek. Stanowią znak przeszłości i tradycji, która przenika do czasów współczesnych, stając się elementem tożsamości kolejnych mieszkańców Muranowa. W końcowych partiach książki widmo pana Izaaka, ulicznego skrzypka, zagłodzonego w warszawskim getcie, gra tajemniczą melodię, która opływa całą dzielnicę.

Kolorowa jak koraliki panów Alfusów melodia rozpływa się wzdłuż szarych domów, płynie ich tunelem w stronę niebieskiego wieżowca, który się nazywa Intraco, mija opustoszałe wnętrze, tam, gdzie kiedyś były delikatesy, odbija się od nowego salonu fryzjerskiego, nowego, bo salon "Otello" po drugiej stronie ulicy zamieniono na afrykański barek. (...) Wszyscy, chłopcy z brodami i kucykami, dziewczęta w powiewnych sukienkach, o kolorowych włosach i z kolczykami w nosie, wszyscy słuchają koralikowej melodii, a ona biegnie ulicą Stawki, tam, gdzie z rampy kolejowej odwożono ludzi do obozów z kolczastymi drutami, i skręca w lewo, płynie, owijając się o strzeliste wieżowce ku Dworcowi Gdańskiemu, skąd odjeżdżali wypędzani z kraju ludzie (Harasimowicz 2018, 185).

Muzyka to wyraz troski, jaką dawni mieszkańcy otaczają lokatorów budynków wzniesionych na gruzach getta, ale i znak pamięci przekazywanej potomnym. Melodia płynąca ulicami, nitka, na którą ktoś nawleka koraliki, są jak opowieść o dawnych czasach i świadectwo minionej kultury.

Bohaterki i bohaterowie przywołanych opowieści szyją, dziergają, haftują, nawlekają koraliki na wątłą nić, aby choć przez chwilę przywrócić odrobinę normalności. Cerują pokawałkowany świat i zaszywają szczeliny istnienia (Brach-Czaina 1999, 12). Wiedzą, że przywrócenie boskiej harmonii nie jest możliwe, ale uparcie oplatają nićmi rzeczywistość w nadziei, że stanie się ona mniej bolesna i łatwiejsza do zniesienia. Kazia Łobodziec i jej przyjaciółka Rózia dziergają ciepłe swetry dla całej rodziny i szykują wyprawkę dla nowo narodzonej Cesi, aby w miarę możliwości chronić ją przed trudami zimowej przesiedleńczej podróży $\mathrm{w}$ bydlęcym wagonie.

${ }^{2}$ Ligocka R., 2001, Dziewczynka w czerwonym płaszczyku, Kraków. 
Dzięki nicianym robótkom mała Zosia jest w stanie przetrwać godziny samotności, Jutce uda się opuścić getto, a podopieczny Korczaka buduje więź ze zmarłym dziadkiem. Każde z nich na swój sposób tka gobelin, podejmując raczej tradycję rozpamiętującej niesprawiedliwość Arachne niż Ateny wpisującej się w obowiązujący porządek. Kolejne wątki układają się w opowieść o codziennej walce z losem urastającej czasem do rangi bohaterstwa, stają się głosem skrzywdzonych, którzy nigdy nie znaleźli się po stronie zwycięzców. Arachnologia, w polskiej recepcji odczytywana często jako kolejna wersja somatopoetyki (Świerkosz 2017, 28), może znaleźć zastosowanie $\mathrm{w}$ badaniu nie tylko kobiecych, autobiograficznych narracji, wymykających się patriarchalnemu porządkowi. Skazani na wykluczenie, dotknięci Zagładą powracają w postpamięciowych opowieściach, jak Arachne zaświadczając o nadużyciach władzy i niesprawiedliwości historii.

„Wszyscy krawcy wyjechali” - tak zatytułowana została rozmowa dotycząca sytuacji Żydów w PRL, którą z Natalią Aleksiun i Dariuszem Stolą przeprowadziła Barbara Polak. Kultura żydowska jest nieobecna w polskiej współczesności - próżno szukać sklepiku Peśki w Gródku Jagiellońskim, nie ma fabryczki braci Alfusów na warszawskich Nalewkach, żydowskie dzielnice, warsztaty, synagogi zniknęły z pejzażu polskich miast. Pozostała jednak nić pamięci - opowieść, która oplata przestrzeń i tka postpamięciową narrację. Losy Zosi, Arona, Jutki i wielu, wielu innych nakładają się palimpsestowo na powojenny krajobraz, jak gdyby wyhaftowane na współczesnym gobelinie. Literatura dla dzieci, umożliwiając młodym czytelnikom odkrywanie wyszywanych czerwoną nicią historii, przypomina o przedwojennej Polsce wielokulturowej, uczy szacunku i otwartości, przestrzega przed niegodziwością, a nade wszystko przyczynia się do odkrywania i budowania tożsamości. Analizowanie tych motywów na lekcjach polskiego może przypominać wędrówkę przez labirynt tekstów w poszukiwaniu prawdy i pozwoli umocnić jej obecność w zbiorowej świadomości.

\section{Bibliografia:}

Biblia Tysiąclecia. Pismo Święte Starego i Nowego Testamentu, 2020, Poznań, http://www.biblia.pl (dostęp: 5.02.2021).

Brach-Czaina Jolanta, 1999, Szczeliny istnienia, Warszawa.

Chmielewska Iwona, 2011, Pamiętnik Blumki, Poznań.

Combrzyńska-Nogala Dorota, 2018, Bezsenność Jutki, Rusinek J. (il.), Łódź.

Gołębiewska-Sucholeska Agnieszka, 2018, Nić/Przędza, w: Wróblewska V. (red.), Słownik polskiej bajki ludowej, Toruń, https://bajka.umk.pl/ (dostęp: 6.02.2021).

Grądziel-Wójcik Joanna, 2017, Przymiarki do istnienia. Wątki i tematy poezji kobiet XX i XXI wieku, Poznań.

Harasimowicz Cezary, 2018, Mirabelka, Kurczewska M. (il.), Warszawa. 
Jaromir Adam, Cichowska Gabriela, 2014, Ostatnie przedstawienie panny

Esterki, Poznań.

Nora Pierre, 1974, Mémoire collective, w: Faire de l'histoire, sous la dir. Le Goff de, Nora P., Paris, s. 401.

Sikorska Magdalena, Smyczyńska Katarzyna, 2014, Ewangelia według Korczaka. „Pamiętnik Blumki” Iwony Chmielewskiej, w: Niesporek-Szamburska B., Wójcik-Dudek M., Zok-Smoła A. (współpr.), Wyczytać świat - międzykulturowość w literaturze dla dzieci i młodzieży, Katowice, s. 151-160.

Sontag Susan, 1986, O fotografii, Magala S. (przeł.), Warszawa.

Szpociński Andrzej, 2008, Miejsca pamięci (lieux de mémoire), „Teksty Drugie”, nr 4, s. 11-20.

Świerkosz Monika, 2017 Arachne i Atena. Literatura, polityka i kobiecy klasycyzm, Kraków.

Tuszyńska Agata, Chmielewska Iwona, 2020, Mama zawsze wraca, Warszawa.

Wójcik-Dudek Małgorzata, 2016, W(y)czytać zagładę: praktyki postpamięci $w$ polskiej literaturze XXI wieku dla dzieci i młodziézy, Katowice.

Wszyscy krawcy wyjechali. O Żydach w PRL z Natalia Aleksiun i Dariuszem Stola rozmawia Barbara Polak, 2005, „Biuletyn IPN”, nr 11, https://www.polska1918-89.pl/pdf/wszyscy-krawcy-wyjechali,6144.pdf (dostęp: 2.02.2021).

Ze skarbnicy midraszy, 1995, Friedman M. (przeł.), Wrocław.

\section{O Autorce:}

Agnieszka Kwiatkowska - dr hab. prof. UAM, pracuje w Zakładzie Literatury XX wieku, Teorii Literatury i Sztuki Przekładu IFP UAM, zaangażowana w prace Zespołu ds. Badań nad Kulturą i Literaturą dla Dzieci UAM, badaczka literatury polskiej XX wieku, autorka prac poświęconych polskiej poezji dwudziestowiecznej (m. in. monografii Tradycja, rzecz osobista na temat twórczości Juliana Przybosia oraz części poświęconej poezji dla dzieci w tomie Stulecie poetek) oraz twórczości dla dzieci (publikowała na temat Danuty Wawiłow, Joanny Mueller, Anny Podczaszy, Ewy Szelburg-Zarembiny, Doroty Terakowskiej, Cezarego Harasimiowicza, Rafała Witka). Obecnie bada kreację odbiorcy w najnowszej polskiej poezji dla dzieci. 
